\title{
Andrea's Dilemma: "I like the freedom that we got to draw whatever we wanted to, but I don't like the way we choose what we want to draw"
}

\section{Lisa Schoenfielder}

For three years I traveled to a rural lowa community to teach middle school boys and girls in a gifted art program. The Special Talent Program In Art met at Wellman Elementary, in the art room, every other Monday afternoon for two hours throughout the school year. Wellman Elementary was a part of the Mid-Prairie School District, a consolidation of six rural communities that spans 215 square miles, located about 25 minutes driving distance from lowa City and the University of lowa. My research has involved composing narrative case studies of students art making strategies. Andrea was a sixth grade student in the class whose situation over time, led me to "draw invisible lines" (Paley, 1990, p.xi) between what she and other children did and what could be learned.

When it came time to make the cover for her artist's book, Andrea encountered the physical properties of paint, canvas, and water which became a grounding for her reinterpretation of an element from her story about the time she fell off her horse. When she painted a solid mass of lavender on a canvas board, some of the paint became swirled and mottled where a part of the surface had accidentally become wet. Andrea tried to blot up some of the water with a paper towel giving the solid mass an atmospheric effect. Kenneth Beittel (1973) spoke of a moment in the expressive act of an art making experience "where the conversion from unreflective to reflective thought comes about" (p.56). Marilyn Zurmuehlen (1990) noted "the concrete physicality of a medium is a basis for reciprocity between makers and their materials, a grounding for reflective attention" (p.4), eliciting a shift "that distinguishes merely doing something with art materials from making art" (Zurmuehlen, 1992, p. 2). In that moment of reflection the sky-like effect gave Andrea the idea to repeat an image from the artist's book she had been working on for a number of weeks in class. The image was of her horse having broken into a full run with Andrea flying out of the saddle holding on for dear life, only this time, Andrea turned the configuration around 90 degrees, so the horse and figure were flying straight up into space rather than moving horizontally across the page as depicted in her artist's book.

At the bottom of the book cover Andrea painted the very top of the planet earth so that it looked as if horse and rider were ascending into the unknown. Uncharacteristically, Andrea rushed to where I was, holding the wet painting out in front of her for me to see. For the first time that year, Andrea 
was pleased with what she had made. In her reordering and abstracting of the image Andrea had recovered and embraced metaphorically something of what she encountered when riding her horse. With an emerging piece of art, Beittel (1982) stated, "it is not what the author intends but what the text actually brings forth for us ..." (p. 19). The artist in creating something brings all of her or his resources or "pre-reflective experience" to bear upon the work of art. This moving forward into the present is an act that creates an "invitation", according to Beittel, to recover bygone times, gaining insight into that experience.

The painter Ben Shahn (1957) was so familiar with this moment of reflection that Beittel and Zurmuehlen spoke of, that he named the contemplative voice posed at this juncture the artist's "inward critic". Shahn (1957) said "the artist must function and act as two people. On the one hand the artist is the imaginer and producer. But ...Also the critic" ( p.34). In first preparing to teach in the gifted art program my question was "what art experiences should I provide these students?" Keeping in mind the philosophies of Zurmuehlen, Beittel, and Shahn, I tried to set up a situation where the art students could make choices, coming to know better in themselves an interpretative inner critic who revises or refines an idea, as Andrea had experienced in making the cover to her artist's book.

But Andrea had not always met with such success. At the end of the school year I asked the class to give a written response to some questions concerning the gifted art program. "What did you like best about our past year", was the first question I posed to students. Andrea answered, "I liked the freedom that we got to draw whatever we wanted to." Another question, "What did you like least about STP art class?" evoked this response from Andrea: "I don't like the way we choose what we want to draw." What did Andrea's contradicting ștatement mean? On the back of Andrea's Xeroxed sheet were sketches she had made while students in the class finished writing their response to the questions I had asked. The three horses she had drawn and scribbled out caused me to reflect on the past year and provided some explanation for Andrea's written comments. This was not the first time I had seen Andrea lose confidence to complete a horse drawing. Could Andrea have been trying to say, "I like freedom to choose my subject matter, but I don't like it because the thing that I want to draw is too difficult for me?" Responses such as Andrea's have led me to think about the inner critic strategies gifted students put to work in order to accomplish satisfactorily, conceived images of objects, persons, or events.

My first instinct toward situations I encountered with Andrea was to believe that she was lacking an essential ingredient needed to be in the gifted art program. Andrea was committed to something, to be sure, though 
she had trouble following through with her plans. Most students in class became more committed to their projects as they invested more time and effort, but Andrea lost interest in her projects over time. With the exception of her cover, this seemed to be true of the artist's book Andrea made over a period of class sessions.

The day the children started on sculptural environments and artist's books Andrea was one of a number of students less sure of what to make. Andrea had many stories about her horse, so many that it was difficult for her to tell the class about a single one. As children listened, laughed, and told their own stories in relation to artist's books we looked at from the year before, Andrea seemed excited. She laughed and listened intently to the stories and plans others had for art they might make but she began to chew nervously on the end of her pencil as she became one of the last to talk about her ideas. Andrea may have thought about the horse that she rode everyday, fed, groomed, and took to horse shows. When the attention turned to her she did not tell a story but said flatly that she would make a book about her horse. Some children could sit back and enjoy their ideas but Andrea from the beginning was frustrated. It was as if all of her horse experience worked against her when she tried to make her story-telling and image-making skills equal her knowledge of equestrianship.

Andrea began a very small sketch of a horse on a large piece of paper but before she completed it she x'd it out and started a new sketch. Through most of the class period Andrea started, stopped, and restarted sketches of horses as she participated in the conversation at her table that grew out of the earlier discussion of artist's books. The students continued to swap stories as they began working on books and sculpture. Andrea told about the time she was knocked off her horse by a tree limb. The next time we met it was this story that she remembered and began to pursue in a series of drawings.

Andrea started making the drawings for her book, first using pencil and then outlining in black fine point marker. As she outlined each drawing the image became more pronounced and permanent on the page. Andrea liked the contrast the dark marker made but she also became more aware of aspects of her horse that seemed unchangeable once she had outlined in marker. After Andrea had worked for a few class sessions on her book she continued working on it at home. Occasionally students in the two week time period between class did forget to bring their work back and were genuinely upset that they did not have the thing they wanted to be working on at school. On other occasions children left something behind because consciously or unconsciously it was a way for them to abandon the project. After completing several pages of her story, drawing with pencil, and then 
outlinging the image with black marker, Andrea left the book at home for good.

When Andrea started her book the second time she worked only in pencil and focused more on the humorous element of the story, using familiar cartoon techniques. As she worked Andrea became increasingly discouraged and ready to give up the project altogether. At some point Andrea, wanting to be done with the book once and for all, focused more on whatever it would take to satisfy me. As I thought about her situation later, I realized that all of the children, at just about any moment might find themselves in a similar position to Andrea's because of a number of circumstances in their particular artmaking.

I first mistook Andrea's lack of staying power as her not wanting to take the time and effort to make her drawings as good as they could be. However it became evident that Andrea's inner critic was as Ben Shahn (1957) described, "prompted by taste, highly personal, experienced and exacting" (p. 35). After spending a number of weeks making two different artist's books Andrea was still not satisfied with the drawings she had made. Upon reflection, I realized Andrea's problem may have initially seemed different from the other children, but in actuality it was the same dilemma all the students encountered at some point as they met with their desire to depict something in a particular way and the difficulties this presented.

At the end of the school year when I looked at Andrea's written response and sketches I finally understood better her predicament. Giving Andrea choices produced for her an opportunity to face the gap between what is and what might be, in other words, to begin to identify the obstacles that prevented her from making her drawings look the way she thought they should. In her drawing as well as her written response Andrea attempted to name these obstacles to herself and to me. "I like the freedom," she said but, "I don't like the way we choose what we want to draw." At a point in her art making, in order to make better choices, Andrea needed more options. It is at times as Maxine Greene (1978) stated "if we knew how to identify openings in our lived situations, if we could actualize what we recognize to be our preferences, we would multiply our occasions for choice." (p.154)

When the work of children's inner critic is considered a number of questions and issues emerge. For me, teaching in a gifted and talented program meant knowing how to respond better to the choices and strategies children, like Andrea, employ when they work for a sustained period of time on their art. Andrea struggled to make a more satisfying horse drawing which led me to consider how and when I could impart more precise technical direction to help her produce a more satisfying drawing. Andrea's choices led 
me to know better how to be her teacher. Within a choice centered curriculum I gained an understanding of children's artmaking strategies and carne to recognize these strategies as similar to my own and other artists.

\section{References}

Beittel, K. (1973). Alternatives For Art Education Research: Inquiry Into the Making of Art. Dubuque: Wm. C. Brown.

Beittel, K. (1982). Metaphor as image of the round future. Visual Arts Research, Fall, 19-23.

Greene, M. (1978). Landscapes of Learning. New York: Teachers College Press.

Paley, V. (1990). The Boy Who Would Be a Helicopter. Cambridge, MA: Harvard University Press.

Shahn, B. (1957). The Shape of Content. Cambridge, MA: Harvard University Press.

Zurmuehlen, M. (1990). Studio art: Praxis, Symbol, Presence. Reston, VA:The National Art Education Association.

Zurmuehlen, M. (1992, May). Studio Art: Shaping Our Individual and Collective Life Stories. Paper presented at the conference of the National Education Association, Phoenix, AZ. 